\title{
İlkokul ve Ortaokul Öğrencilerinin Yazma Eğilimlerinin İncelenmesi
}

\author{
Hümeyra UYSAL \\ Marmara Üniversitesi \\ humeyrauysal11@gmail.com \\ ORCID ID: 0000-0003-4805-8079 \\ Sabri SIDEKLİ \\ Muğla Sitkı Koçman Üniversitesi \\ ssidekli@mu.edu.tr \\ ORCID ID: 0000-0003-3202-6451 \\ Kevser TOLUN \\ Milli Eğitim Bakanlığ \\ kevsertolun@gmail.com \\ ORCID ID: 0000-0001-6397-744X
}

Araştırma Makalesi

Geliş Tarihi: 07.10.2020

Revize Tarihi: 25.12 .2020

DOI: $10.31592 /$ aeusbed.807005

Kabul Tarihi: 08.01.2021

\section{Attf Bilgisi}

Uysal, H., Sidekli, S. ve Tolun, K. (2021). İlkokul ve ortaokul öğrencilerinin yazma eğilimlerinin incelenmesi. Ahi Evran Üniversitesi Sosyal Bilimler Enstitüsü Dergisi, 7(1), 254-257.

\section{$\ddot{O Z Z}$}

Türkçe öğretim programının temel amacı öğrencilerin iyi birer yazar olması ve kendilerini yazılı olarak doğru bir şekilde ifade edebilmesidir. Programın bu amacı doğrultusunda öğretmenlerin öğrencilere yazma bilincini aşlaması, onları iyi birer yazar olarak yetiştirmesi gerekmektedir. Ayrıca programın bir diğer amacı öğrencilerin yazmaya yönelik olumlu duygu ve davranış geliştirmesini de sağlamaktır. Bu bağlamda çalışmanın amacı, ilkokul ve ortaokul öğrencilerinin yazma eğilimi algılarını cinsiyet ve sınıf düzeyi değişkenlerine göre incelemektir. Tarama modelinde desenlenen araştırma, 2016-2017 eğitim-öğretim yılında Muğla il merkezinin farklı semtlerinde bulunan sosyoekonomik düzeyi birbirine yakın olan ilkokullar ve ortaokullar arasından toplam 4 köy okulunda gerçekleştirilmiştir. Araştırmaya 2., 3., 4., 5., 6., 7., ve 8. sinıflarda öğrenim gören toplam 294 öğrenci katılmıştır. Veri toplama aracı olarak "Yazma Eğilimi Ölçeği” kullanılmıştır. Elde edilen verilerinin analizinde bağımsız gruplar t-testi ve tek yönlü varyans analizinden (ANOVA) yararlanılmıştır. Araştırmadan elde edilen sonuçlara göre, tüm sınıf düzeyindeki öğrencilerin yazma eğilimlerinin genel olarak ortalamanın üzerinde olduğu ortaya çıkmıştır. Ayrıca kız öğrencilerin erkek öğrencilere göre yazma eğilimlerinin daha yüksek olduğu saptanmıştır.

Anahtar Kelimeler: Yazma, yazma eğilimi, ilkokul, ortaokul.

\section{Examination of Writing Tendencies of Primary and Secondary School Students}

\begin{abstract}
The main purpose of the Turkish curriculum is for students to be good writers and to express themselves correctly in writing. In line with this purpose of the program, teachers should instill the awareness of writing in students and raise them as good writers. In addition, another aim of the program is to enable students to develop positive feelings and behaviors for writing. It is also to enable students to develop positive feelings and behaviors for writing. In this context study is to examine the perceptions of primary and secondary school students' writing disposition according to gender and grade level variables. The study, which was designed in the screening model, was carried out in a total of 4 village schools among the primary and secondary schools whose socioeconomic level is close to each other in different districts of Muğla city center in the 2016-2017 academic year. A total of 294 students attending from $2 \mathrm{nd}, 3 \mathrm{rd}, 4 \mathrm{th}, 5 \mathrm{th}, 6 \mathrm{th}, 7 \mathrm{th}$ and 8 th grades participated in the study. "Writing Tendency Scale" was used as a data collection tool. Independent groups t-test and one-way analysis of variance (ANOVA) were used in the analysis of the data obtained. According to the results obtained from the research; it was found that writing tendencies of students at all grade levels were generally above average. In addition, female students were found to have higher tendency to write than male students.
\end{abstract}

Keywords: Writing, writing tendency, primary school, secondary school.

\section{Giriş}

Dil, insanların arasında iletişimi sağlayan en önemli araçtır. İnsanlar, dil vasıtasıyla kurduğu iletişimde anlamaya dayal1, dinleme-okuma ve anlatmaya dayalı, konuşma-yazma olarak dört temel dil becerisini kullanmaktadır. Dil öğretimi de bu dört temel dil becerisini etkili bir biçimde öğretilmesini 
kapsamaktadır (İşeri ve Ünal, 2010). Dilin kullanım alanları; dinleme, konuşma, okuma, yazma, görsel okuma ve görsel sunu olarak belirlenmiştir (Aydın Yılmaz, 2007; Güneş, 2013, 2007a, 2007b). Milli Eğitim Bakanlığı (MEB) (2015) 1. ve 8. sınıflar için hazırladığı Türkçe dersi programında dil öğrenme alanlarını sözlü iletişim, okuma ve yazma şeklinde üç öğrenme alanına düşürmüştür ve değiştirmiştir. MEB (2019) Türkçe Dersi Öğretim Programında ise dil öğrenme alanları; dinleme, konuşma, okuma ve yazma olarak yer almıştır.

Dört temel dil becerisinden konuşma ve dinlemenin okul dışında kazandırılması mümkündür. Fakat okuma ve yazma becerilerinin kazandırılması için bir eğitim şarttır. Okuma ve yazma becerisi ilkokul kurumlarında Türkçe dersleriyle kazandırılmaya çalışılmaktadır (Belet ve Yaşar, 2007). Öğrenme alanlarından en son ve en zor gelişen ise yazmadır. Güneş’e (2013) göre yazma, zihnimizdeki duyguları, düşünceleri, istekleri ve olayları belli kurallar doğrultusunda sembollerle ifade edilmesi ve zihinde yapılandırılmış bilgilerin yazıya dökülmesi işlemi olarak tanımlanmıştır. Prior (2008) yazmayı, yazar ve okuyucu arasında anlam kurabilen etkileşimli bir süreç olarak tanımlamıştır. Ayrıca yazma; zamana ve mesafeye bakmadan uzakta olan insanlarla iletişim kurmayı, bilgi edinmeyi, sunmayı, bilgiyi aktarmayi, istekleri dile getirmeyi, bireylerin kendini ifade edebilmesini sağlamaktadır (Sidekli, 2012).

Öğrencilerin iyi birer yazar olması, yazma sevgisi ve yazma alışkanlığı kazanmaları Türkçe Öğretim Programının temel amaçlarından biridir (MEB, 2015; 2017; 2019). Cemaloğlu'na (2001) göre, Türkçe eğitiminin hedeflerinden birisini şöyle açıklamıştır; öğrencilerin görüp izlediklerini, dinlediklerini, bildiklerini, okuduklarını, incelediklerini, düşündüklerini ve tasarladıklarını sadece söz ile değil, aynı zamanda yazı ile de doğru ve amaca uygun olarak anlatma beceri ve alışkanlığı kazandırmaktır. Aktaş ve Gündüz (2003) yazmanın amacı bireyin, gözlem ve bilgi birikiminden yararlanarak; kendi duygu ve düşüncelerini, doğru, etkili ve güzel bir biçimde okuyucuya yansıtması şeklinde belirtmiştir.

Yazma becerisi, beyinde yapılandırılan bilgilerin yazıya dökülmesi olarak belirtilmiştir (Güneş, 2007a). MEB'in (2015) Türkçe Öğretimi 1-8 ders programında “yazma becerisinin geliştirilmesiyle; öğrencilerin duygu, düşünce, hayal, tasarı ve izlenimleri ile bir konuda görüşlerini ve tezlerini dilin imkânlarından yararlanarak yazılı anlatım kurallarına uygun şekilde anlatmaları, yazmayı kendini ifade etmede bir alışkanlığa dönüştürmeleri ve yazma yeteneği olanların bu becerilerini geliştirmeleri amaçlanmaktadır".

İlkokul öğrencilerin yazma becerilerini geliştirmek için öğrencilere öğretici yazılar yazdırmanın yanı sıra dünyayı algılamaları ve anlatımlarında kendi görüş, düşünce, ifade ve hayal güçlerini kullanmalarına da imkân tanımak gerekir (Bağc1, 2017). Öğrencilerin yazma becerisini geliştirmek için yazmanın bilişsel ve psikomotor alanının yanında duyuşsal alanının da dikkate alınması gerekmektedir. Öğrencilerin yazma becerisine ilişkin eğilimlerinin tespit edilerek olumlu yönde geliştirilmesi önem arz etmektedir. Yazma eğilimi, kişilerin yazmaya karşı içsel olarak istekli olmasıdır. Yazma eğilimi kişiyi yazmaya daha yatkın hale getiren duyuşsal bir güç olarak tanımlanabilir. Yazma eğilimi, kişinin yazmaya olan hevesi, heyecanı, tutkusu olarak da ifade edilebilir.

McClenny (2010) yazma eğiliminin biliş, duygu ve sosyal bağlam olarak üç boyuttan oluştuğunu söylemektedir. Biliş boyutu; yazma eğilimin temel yapısında yatan bilgi ve yetenekler olarak ifade edilmiştir. Duygu boyutu; üst biliş, motivasyon, öz-yeterlik ve devam ettirme gibi kişinin herhangi bir etkinliğe katılmasındaki istekliliğiyle ilişkilendirilmiştir. Sosyal bağlam boyutu ise biliş ve duygu boyutunun birleşiminden meydana gelmektedir. Piazza ve Siebert (2008) ise yazma eğiliminin güven, kararlık ve tutkudan oluşan üç farklı duygusal boyuttan meydana geldini ifade etmiştir. Güven boyutu, kişinin bir yazar olarak etkisini ve yazma yeteneğindeki inancını temsil etmektedir. Kararlık boyutu, yazma işini devamlı olarak yapma, yazmayla sürekli ilgilenme ve yazmak için zaman ayırmadan meydana gelmektedir. Tutku boyutu ise kişinin yazmaya kendini tüm gücüyle vermesi, devamlı yazmak istemesi ve zamanını yazmaya ayırmaktan mutluluk duyması olarak ifade edilmektedir. 
Yapılan bu araştırmanın amacı, ilkokul ve ortaokul (2., 3., 4., 5., 6., 7. ve 8. sinıf) öğrencilerinin yazma eğilimlerini sınıf ve cinsiyet değişkeni açısından incelenmesi ve ilkokul ve ortaokul öğrencilerin yazma düzeylerini belirlemektir. Bu amaç doğrultusunda, aşağıdaki alt problemlere yanıt aranmıştır:

1. İlkokul ve ortaokul öğrencilerinin yazma eğilimleri ne düzeydedir?

2. İlkokul ve ortaokul öğrencilerinin yazma eğilimleri, cinsiyet değişkenine göre farklılık göstermekte midir?

3. İlkokul ve ortaokul öğrencilerinin yazma eğilimleri, sınıf düzeyi değişkenine göre farklılık göstermekte midir?

\section{Yöntem}

Bu bölümde, araştırmanın modeli, evren ve örneklem, veri toplama aracı ve verilerin analizine ilişkin detaylı bilgiye yer verilmiştir.

\section{Araștırmanın Modeli}

Araştırma nicel araştırma türlerinden olan tarama modeli ile yapılmış olup tarama çeşitlerinden genel tarama modeli uygun görülmüştür. Araştırmanın genel tarama modeli şeklinde tasarlanmasının sebebi; evrenin tamamından bir örneklem seçilerek bu örneklemin sonuçlarını evrene genellemeyi sağladığı için genel tarama modeli seçilmiştir. Karasar (2017) genel tarama modelini, çok sayıda elemandan oluşan bir evrende evren hakkında genel bir yargıya varmak maksadıyla evrenin tümü ya da evrenden alınacak örneklem üzerinden yapılan model olarak tanımlamıştır.

\section{Evren ve Örneklem}

Araştırmanın evrenini Muğla il merkezinde öğrenim gören 2016 - 2017 Eğitim-Öğretim yılında ilkokul ve ortaokul seviyelerinde öğrenim gören öğrenciler oluşturmaktadır. Örneklem ise Muğla il merkezinin farklı semtlerinde bulunan toplam 4 resmi köy ilkokulu ve köy ortaokulunda öğrenim görmekte olan 294 öğrenciden meydana gelmektedir. Ölçek uygulaması yapılan okullar seçilirken, okulların sosyo-ekonomik durumlarının aynı seviyede olmasına dikkat edilmiştir. Sosyo-ekonomik düzeyi düşük okullar araştırmaya dâhil edilmeye çalışılmıştır. Örneklemin seçiminde, amaçsal örnekleme çeşitlerinden benzeşik örnekleme yöntemi benimsenmiştir. Benzeşik örnekleme, evrenden araştırmanın problemine göre benzeşik bir alt grubun veya durumun seçilerek çalışmanın yapılmasına olanak sağlamaktadır (Büyüköztürk, Kılıç Çakmak, Akgün, Karadeniz ve Demirel, 2017). Örneklemeye ikinci sınıf düzeyinden sekizinci sınıf düzeyine kadar tüm sınıf düzeyleri ve sosyo-ekonomik düzeyi birbirine yakın okullar dâhil edilmiştir.

Araştırmaya katılan ilkokul ve ortaokul öğrencilerinin cinsiyete göre dağılımı, yüzde ve frekans değerleri Tablo 1'de verilmiştir.

Tablo 1

Örneklemin Cinsiyete Göre Frekans ve Yüzdeleri

\begin{tabular}{lll}
\hline Cinsiyet & $\mathbf{N}$ & $\mathbf{\%}$ \\
\hline K1z & 150 & 51,0 \\
Erkek & 144 & 49,0 \\
Toplam & 294 & 100 \\
\hline
\end{tabular}

Tablo 1'de görüldüğü üzere araştırmaya 150 kız (\%51) ve 144 erkek (\%49) öğrencinin katılım gösterdiği belirtilmiştir.

Araştırmaya katılan ilkokul ve ortaokul öğrencilerinin sınıf düzeylerine ait yüzde ve frekans bilgileri Tablo 2'de belirtilmiştir. 
Tablo 2

Örneklemin Sinıf Düzeyine Göre Frekans ve Yüzdeleri

\begin{tabular}{cll}
\hline Sinif Düzeyi & N & \% \\
\hline 2 & 22 & 7,5 \\
3 & 28 & 9,5 \\
4 & 33 & 11,2 \\
5 & 54 & 18,4 \\
6 & 45 & 15,3 \\
7 & 56 & 19,0 \\
8 & 56 & 19,0 \\
Toplam & 294 & 100 \\
\hline
\end{tabular}

Tablo 2 incelendiğinde araştırmaya 22 ikinci sınıf $(\% 7,5), 28$ üçüncü sınıf $(\% 9,5), 33$ dördüncü sınıf $(\% 11,2), 54$ beşinci sınıf $(\% 18,4), 45$ altıncı sinıf $(\% 15,3), 56$ yedinci sınıf $(\% 19)$ ve 56 sekizinci sinıf (\%19) öğrencisi katılmıştır.

\section{Veri Toplama Aracı}

Araştırmada veri toplama aracı olarak Piazza ve Siebert (2008) tarafindan geliştirilen, İşeri ve Ünal (2010) tarafından Türkçeye çevrilen ve uyarlanan "Yazma Eğilimi Ölçeği” kullanılmıştır. Ölçek güven, süreklilik ve tutku olmak üzere üç alt boyuttan oluşmaktadır. Güven boyutu 6 maddeden, süreklilik boyutu 4 maddeden, tutku boyutu 11 maddeden meydana gelmekte toplamda ölçekte 21 madde bulunmaktadır. Ölçek, "Tamamen Katılmıyorum" yanıtından "Tamamen Katılıyorum" yanıtına kadar değişkenlik gösteren beş dereceli likert tipi bir ölçektir. Ölçek, bir öğrenci ölçekten en az 21 puan en çok 105 puan alacak şekilde oluşturulmuştur.

İşeri ve Ünal'ın (2010) uyarlama çalışmasında "Yazma Eğilimi Ölçeği”nin güvenilirliğine ilişkin bulgular; ölçeğin tamamında .874; tutku alt boyutunda .882; güven alt boyutunda .734 ve süreklilik alt boyutunda .639 olarak bulmuşlardır. Bu araştırma için Cronbach Alpha güvenilirlik katsayısı ölçeğin tamamı için .893; güven alt boyutu için .806; süreklilik alt boyutu için .749; tutku alt boyutu için ise .914 olarak bulunmuştur.

\section{Verilerin Analizi}

Araştırma verilerinin analizinde istatistik programı kullanılmıştır. Öğrencilerin yazma eğilimi algılarını ortaya koymak amacıyla, öncelikli olarak öğrencilerin yazma düzeyleri ortaya konmuştur. Bunun için öğrencilerin vermiş oldukları cevapların aritmetik ortası verilmiştir. Yazma Eğilimi Ölçeğine verdikleri yanıtların aritmetik ortalama ve standart sapma gibi betimsel istatistikleri hesaplanmıştır. Cinsiyete göre yapılan karşılaştırmalarda bağımsız gruplar t-testi, sınıf düzeyi değişkenlerine göre yapılan karşılaştırmalarda ise tek yönlü varyans (ANOVA) analizi kullanılmıştır. Tek yönlü varyans analizinde anlamlı farklılı̆̆ tespit edilmek için Dunnett - C analizi yapılmıştır.

\section{Bulgular}

İlkokul ve ortaokul öğrencilerinin yazma eğilim düzeyleri Tablo 3’te sunulmuştur.

Tablo 3

Sinıfların Yazma Ë̆ilim Düzeyleri

\begin{tabular}{ccccccccc}
\hline $\begin{array}{c}\text { Sinıflar } \\
\text { Alt Boyutlar }\end{array}$ & 2. Sinıf & 3. Sinıf & 4. Sinıf & 5. Sinıf & 6. Sinıf & 7. Sinıf & 8. Sinıf & $\begin{array}{c}\text { Tüm } \\
\text { Sinıflar }\end{array}$ \\
\hline Güven & 3,23 & 2,91 & 3,01 & 3,11 & 2,74 & 2,89 & 2,82 & 2,94 \\
Süreklilik & 2,42 & 2,55 & 2,62 & 2,88 & 2,63 & 2,34 & 2,29 & 2,53 \\
Tutku & 3,16 & 3,23 & 3,22 & 3,14 & 2,85 & 2,60 & 2,44 & 2,88 \\
\hline
\end{tabular}

Tablo 3 incelendiğinde; güven alt boyutunda ikinci sınıfların puan ortalaması $(\bar{X}=3,23)$ diğer sınıf düzeylerinden yüksek, süreklilik alt boyutunda beşinci sınıfların puan ortalaması $(\bar{X}=2,88)$ diğer 
sınıf düzeylerinden yüksek ve tutku alt boyutunda üçüncü sinıfların puan ortalaması $(\bar{X}=3,23)$ diğer sınıf düzeylerinden yüksek olduğu ortaya çıkmıştır. İkinci, yedinci ve sekizinci sınıf düzeylerinin tüm alt boyutlarında en yüksek puan ortalaması güven alt boyutunda; üçüncü, dördüncü, beşinci ve altınc1 sınıf düzeylerinin tüm alt boyutlarında en yüksek puan tutku alt boyutunda olduğu görülmüştür. Süreklilik alt boyutunda ise herhangi bir sınıf düzeyi en yüksek puanı alamamıştır. Tüm sınıfların alt boyutlardaki puan ortalamasına bakıldığında, en yüksek puan ortalaması güven alt boyutunda $(\bar{X}=2,94)$, ikinci en yüksek puan ortalaması tutku alt boyutunda $(\bar{X}=2,88)$ ve en az puan ortalaması da süreklilik alt boyutunda $(\bar{X}=2,53)$ olduğu yapılan analizler sonucunda ortaya çıkmıştır.

Güven, süreklilik ve tutku alt boyutunda cinsiyete göre karşılaştırma yapmak için bağımsız gruplar $\mathrm{t}$ testi yapılmıştır. Yapılan analizin sonuçları Tablo 4'te verilmiştir.

Tablo 4

Güven, Süreklilik ve Tutku Boyutlarının Cinsiyete Göre Karşılaştırılması

\begin{tabular}{llcccccc}
\hline & & $\mathbf{N}$ & $\bar{X}$ & Ss & sd & t & p \\
\hline Güven & K1z & 150 & 3,09 &, 68 & 292 & 3,27 &, 00 \\
Süreklilik & Erkek & 144 & 2,77 &, 99 & & &, 22 \\
\multirow{4}{*}{ Tutku } & K1z & 150 & 2,54 &, 94 & 292 &, 83 \\
& Erkek & 144 & 2,51 &, 97 & & & \\
& K1z & 150 & 3,00 &, 82 & 292 & 2,33 &, 02 \\
\hline
\end{tabular}

Yazma eğilimlerinin tüm alt boyutlarda, cinsiyete göre anlamlı farklılık olup olmadığını ortaya koymak için yapılan ilişkisiz örneklemler $\mathrm{t}$ testi yapılmıştır. Güven alt boyutunda kızların test puan ortalaması ile $\left(\bar{X}_{\text {güven-kiz }}=3,09\right)$ güven alt boyutunda erkeklerin test puan ortalamas1 $\left(\bar{X}_{\text {güven-erkek }}=2,77\right)$ arasında k1zların lehine anlaml farklılık bulunmuştur $\left[\mathrm{t}_{(292)}=3,27 ; \mathrm{p}<, 05\right]$. Süreklilik alt boyutuna bakıldığında, kızların test puan ortalaması ile $\left(\bar{X}_{\text {süreklilik-kız }}=2,54\right)$ erkeklerin test puan ortalaması $\left(\bar{X}_{\text {süreklilik-erkek }}=2,51\right)$ arasında anlamlı farklılık görülmemiştir $\left[\mathrm{t}_{(292)}=, 22 ; \mathrm{p}>, 05\right]$. Tutku alt boyutu incelendiğinde, kızların test puan ortalaması ile $\left(\bar{X}_{\text {tutku-kız }}=3,00\right)$ erkeklerin test puan ortalaması $\left(\bar{X}_{\text {tutku- }}\right.$ erkek $=2,76)$ arasında kızların lehine anlamlı farklılık olduğu analiz sonucunda ortaya çıkmıştır $\left[\mathrm{t}_{(292)}=\right.$ $2,33 ; \mathrm{p}<, 05]$. Cinsiyete göre alt boyutlarda güven ve tutku boyutunda anlamlı farkl1lık bulunmuş fakat süreklilik alt boyutunda anlamlı bir farklılık bulunmamıştır. Süreklilik alt boyutunda anlamlı farklılık bulunmamasına rağmen kızların yazma eğilim puan ortalamaları erkeklerin yazma eğilim puan ortalamalarından yüksek çıkmıştır.

İkinci sınıfların cinsiyete göre karşılaştırması tüm alt boyutlarda güven, süreklilik ve tutkuya ait yapılan bağımsız gruplar t testi sonuçları Tablo 5'te verilmiştir.

Tablo 5

2. Sinıfların Güven, Süreklilik ve Tutku Alt Boyutlarının Cinsiyete Göre Karşılaştırılması

\begin{tabular}{|c|c|c|c|c|c|c|c|}
\hline \multicolumn{2}{|l|}{ 2. Siniflar } & \multirow{2}{*}{$\begin{array}{c}\mathbf{N} \\
8\end{array}$} & \multirow{2}{*}{$\frac{\overline{\bar{X}}}{3,40}$} & \multirow{2}{*}{$\begin{array}{c}\text { Ss } \\
, 44\end{array}$} & \multirow{2}{*}{$\begin{array}{l}\text { sd } \\
20\end{array}$} & \multirow{2}{*}{$\begin{array}{c}\mathbf{t} \\
, 85\end{array}$} & \multirow{2}{*}{$\begin{array}{l}\mathbf{p} \\
, 41\end{array}$} \\
\hline Güven & $\mathrm{K}_{1 \mathrm{Z}}$ & & & & & & \\
\hline & Erkek & 14 & 3,13 & ,81 & & & \\
\hline \multirow[t]{2}{*}{ Süreklilik } & $\mathrm{K}_{1 \mathrm{z}}$ & 8 & 2,41 & 1,10 & 20 &,- 04 & ,97 \\
\hline & Erkek & 14 & 2,43 & 1,20 & & & \\
\hline \multirow[t]{2}{*}{ Tutku } & $\mathrm{K}_{1 \mathrm{Z}}$ & 8 & 3,25 &, 60 & 20 & , 40 & ,69 \\
\hline & Erkek & 14 & 3,10 & ,93 & & & \\
\hline
\end{tabular}

Tablo 5 incelendiğinde ikinci sınıfların; güven, süreklilik ve tutku alt boyutlarında anlamlı farklı1ık bulunmamıştır. Tüm alt boyutların ortalamalarına bakıldığında ise güven ve tutku alt boyutunda kızların ortalaması yüksek, süreklilik alt boyutunda ise erkeklerin ortalaması yüksek çıkmıştır.

Üçüncü sınıfların cinsiyete göre karşılaştırması tüm alt boyutlarda yapılan bağımsız gruplar $\mathrm{t}$ testi sonuçları Tablo 6'da verilmiştir. 
Tablo 6

3. Sinıfların Güven, Süreklilik ve Tutku Alt Boyutlarının Cinsiyete Göre Karşılaştırılması

\begin{tabular}{llllcccc}
\hline 3. Sinıflar & & $\mathbf{N}$ & $\bar{X}$ & Ss & t & df & p \\
\hline Güven & Kız & 14 & 2,92 & 1,28 &, 03 & 26 &, 98 \\
\multirow{3}{*}{ Süreklilik } & Erkek & 14 & 2,90 &, 81 & & & \\
\multirow{2}{*}{ Tutku } & Kız & 14 & 2,59 & 1,07 &, 20 & 26 &, 85 \\
& Erkek & 14 & 2,52 &, 86 & & & \\
& Kız & 14 & 3,20 & 1,07 &,- 21 & 26 &, 83 \\
& Erkek & 14 & 3,27 &, 41 & & & \\
\hline
\end{tabular}

Tablo 6 incelendiğinde üçüncü sınıfların; güven, süreklilik ve tutku alt boyutlarında anlamlı farklılık bulunmamıştır. Tüm alt boyutların ortalamalarına bakıldığında ise güven ve süreklilik alt boyutunda kızların ortalaması yüksek, tutku alt boyutunda ise erkeklerin ortalaması yüksek çıkmıştır.

Dördüncü sınıfların cinsiyete göre tüm alt boyutlarında yapılan bağımsız gruplar t testi sonuçları Tablo 7'de verilmiştir.

Tablo 7

4. Sinıfların Güven, Süreklilik ve Tutku Alt Boyutlarının Cinsiyete Göre Karşılaştırılması

\begin{tabular}{llllllll}
\hline 4. Sinıflar & & $\mathbf{N}$ & $\bar{X}$ & $\mathbf{S s}$ & $\mathbf{t}$ & $\mathbf{d f}$ & $\mathbf{p}$ \\
\hline Güven & Kız & 17 & 3,11 &, 76 &, 77 & 31 &, 45 \\
\multirow{3}{*}{ Süreklilik } & Erkek & 16 & 2,92 &, 67 & & & \\
\multirow{2}{*}{ Tutku } & Kız & 17 & 2,50 &, 97 &,- 47 & 31 &, 64 \\
& Erkek & 16 & 2,66 &, 93 & & & \\
& Kız & 17 & 3,40 &, 65 & 1,69 & 31 &, 10 \\
& Erkek & 16 & 2,98 &, 77 & & & \\
\hline
\end{tabular}

Dördüncü sınıflara ait Tablo 7'ye bakıldığında; güven, süreklilik ve tutku alt boyutlarında anlamlı farklılık bulunmamıştır. Tüm alt boyutların ortalamalarına bakıldığında ise güven ve tutku alt boyutunda kızların ortalaması yüksek, süreklilik alt boyutunda ise erkeklerin ortalaması yüksek çıkmıştır.

Beşinci sınıfların cinsiyete göre güven, süreklilik ve tutku alt boyutlarındaki bağımsız gruplar $t$ testi sonuçları Tablo 8'de yer almaktadır.

Tablo 8

5. Sinıfların Güven, Süreklilik ve Tutku Alt Boyutlarının Cinsiyete Göre Karşılaştırılması

\begin{tabular}{lllllccc}
\hline 5. Sinıflar & & $\mathbf{N}$ & $\bar{X}$ & Ss & $\mathbf{t}$ & $\mathbf{d f}$ & $\mathbf{p}$ \\
\hline Güven & Kiz & 31 & 3,34 &, 51 & 2,65 & 52 &, 01 \\
& Erkek & 23 & 2,80 &, 95 & & & \\
Süreklilik & Kız & 31 & 2,85 &, 93 &,- 29 & 52 &, 77 \\
& Erkek & 23 & 2,92 & 1,02 & & & \\
\multirow{2}{*}{ Tutku } & Kiz & 31 & 3,33 &, 51 & 2,21 & 52 &, 03 \\
& Erkek & 23 & 2,90 &, 92 & & & \\
\hline
\end{tabular}

Tablo 8'de beşinci sınıfların yazma eğilim puanlarının alt boyutları incelendiğinde; güven alt boyutunda yapılan analizler sonucunda anlamlı bir farklılık tespit edilmiştir. Güven alt boyutunda kızların test puan ortalaması ile $\left(\bar{X}_{\text {güven-kız(5.smif) }}=3,34\right)$ güven alt boyutunda erkeklerin test puan ortalaması $\left(\bar{X}_{\text {güven-erkek }(5 . \text { smıt })}=2,80\right)$ şeklinde olup kızların lehine anlamlı bir farklılık saptanmıştır $\left[\mathrm{t}_{(52)}=\right.$ $2,65 ; \mathrm{p}<, 05]$. Süreklilik alt boyutunda ise anlamlı bir farklılık ortaya çıkmamıştır. Süreklilik alt boyutunda anlamlı farklılık olmamasına rağmen erkeklerin puan ortalaması kızların puan ortalamasından daha yüksek olduğu sonucu ortaya çıkmıştır. Tutku alt boyutunda analizler sonucunda anlamlı bir farklılık olduğu sonucuna ulaşılmıştır. Tutku alt boyutu incelendiğinde, kızların test puan ortalaması ile $\left(\bar{X}_{\text {tutku-kız }(5 . \text { smif })}=3,33\right)$ erkeklerin test puan ortalamas1 $\left(\bar{X}_{\text {tutku-erkek }(5 . \operatorname{sinif})}=2,90\right)$ arasinda kızların lehine anlamlı farklılık olduğu analiz sonucunda ortaya çıkmıştır $\left[\mathrm{t}_{(52)}=2,21 ; \mathrm{p}<, 05\right]$. 
Altıncı sınıfların cinsiyete göre tüm alt boyutlarda yapılan bağımsız gruplar $\mathrm{t}$ testi sonuçları Tablo 9' da belirtilmiştir.

Tablo 9

6. Sinıfların Güven, Süreklilik ve Tutku Alt Boyutlarının Cinsiyete Göre Karşılaşstırılması

\begin{tabular}{lllllccc}
\hline 6. Sinıflar & & $\mathbf{N}$ & $\bar{X}$ & Ss & t & df & p \\
\hline Güven & Kiz & 18 & 2,99 &, 63 & 2,09 & 43 &, 04 \\
& Erkek & 27 & 2,57 &, 67 & & & \\
Süreklilik & Kız & 18 & 2,86 &, 74 & 1,51 & 43 &, 14 \\
& Erkek & 27 & 2,47 &, 90 & & & \\
\multirow{2}{*}{ Tutku } & Kiz & 18 & 3,14 &, 59 & 2,00 & 43 &, 05 \\
& Erkek & 27 & 2,66 &, 90 & & & \\
\hline
\end{tabular}

Tablo 9'daki analizler sonucunda; altıncı sınıfların yazma eğilim puanlarının alt boyutları incelendiğinde; güven alt boyutunda anlamlı bir farkl111k olduğu ortaya çıkmıştır. Güven alt boyutunda k1zların test puan ortalamasi ile $\left(\bar{X}_{\text {güven-kzz(6.smif) }}=2,99\right)$ güven alt boyutunda erkeklerin test puan ortalaması $\left(\bar{X}_{\text {güven-erkek(6.sınıf) }}=2,57\right)$ şeklinde olup kızların lehine anlamlı bir farklılık saptanmıştır $\left[\mathrm{t}_{(43)}=\right.$ $2,09 ; \mathrm{p}<, 05]$. Süreklilik alt boyutunda anlamlı bir farklılık ortaya çıkmamıştır. Anlamlı bir farklılık olmamasına rağmen kızların puan ortalaması erkeklerin ortalamasından yüksek olduğu sonucuna ulaşılmıştır. Tutku alt boyutunda da anlamlı bir fark ortaya çıkmıştır. Tutku alt boyutu incelendiğinde, k1zların test puan ortalaması ile $\left(\bar{X}_{\text {tutku-kız(6.smif })}=3,14\right)$ erkeklerin test puan ortalamas $1\left(\bar{X}_{\text {tutku-erkek(6.smif })}=\right.$ $2,66)$ arasında kızların lehine anlamlı farklılık olduğu yapılan analizler sonucunda ortaya çıkmıştır $\left[\mathrm{t}_{(43)}\right.$ $=2,00 ; \mathrm{p}<, 05]$.

Yedinci sınıfların cinsiyete göre yazma eğilimi ölçeğindeki tüm alt boyutlara ilişkin bağımsız gruplar t testi sonuçları Tablo 10'da verilmiştir.

Tablo 10

7. Sinıfların Güven, Süreklilik ve Tutku Alt Boyutlarının Cinsiyete Göre Karşılaştırılması

\begin{tabular}{llllcccc}
\hline 7. Sinıflar & & $\mathbf{N}$ & $\bar{X}$ & Ss & T & df & p \\
\hline Güven & Kız & 29 & 3,02 &, 51 &, 88 & 54 &, 38 \\
\multirow{3}{*}{ Süreklilik } & Erkek & 27 & 2,74 & 1,64 & & & \\
& Kız & 29 & 2,40 &, 88 &, 48 & 54 &, 63 \\
\multirow{2}{*}{ Tutku } & Erkek & 27 & 2,28 &, 96 & & & \\
& Kiz & 29 & 2,77 &, 74 & 1,26 & 54 &, 21 \\
& Erkek & 27 & 2,42 & 1,30 & & & \\
\hline
\end{tabular}

Tablo 10 incelendiğinde yedinci sınıfların; güven, süreklilik ve tutku alt boyutlarında anlamlı farklılık tespit edilmemiştir. Tüm alt boyutların ortalamalarına bakıldığında ise güven, tutku ve süreklilik alt boyutlarında kızların ortalaması erkeklerin ortalamasından daha yüksek çıkmıştır. Kızların tüm alt boyutlarındaki ortama puanı erkeklerden fazladır.

Sekizinci sınıfların cinsiyete göre tüm alt boyutlarda yapılan bağımsız gruplar $\mathrm{t}$ testi sonuçları Tablo 11'de belirtilmiștir.

Tablo 11

8. Sinffların Güven, Süreklilikve Tutku Alt Boyutlarının Cinsiyete Göre Karşılaştırılması

\begin{tabular}{|c|c|c|c|c|c|c|c|}
\hline \multicolumn{2}{|l|}{ 8. Sinıflar } & $\mathbf{N}$ & $\overline{\bar{X}}$ & Ss & t & df & $\mathbf{p}$ \\
\hline \multirow{2}{*}{ Güven } & $\mathrm{K} 1 \mathrm{z}$ & 33 & 2,97 & ,62 & 2,15 & 54 & ,04 \\
\hline & Erkek & 23 & 2,60 & 67 & & & \\
\hline \multirow[t]{2}{*}{ Süreklilik } & $\mathrm{K} 1 \mathrm{z}$ & 33 & 2,23 & ,94 &,- 60 & 54 &, 55 \\
\hline & Erkek & 23 & 2,38 & ,95 & & & \\
\hline \multirow[t]{2}{*}{ Tutku } & $\mathrm{K} 1 \mathrm{z}$ & 33 & 2,45 & ,95 &, 07 & 54 & ,94 \\
\hline & Erkek & 23 & 2,43 &, 81 & & & \\
\hline
\end{tabular}


Tablo 11'deki analiz sonuçları incelendiğinde sekizinci sınıfların yazma eğilim puanlarının alt boyutları incelendiğinde; alt boyutlarından süreklilik ve tutku alt boyutlarında anlamlı farklılık bulunmamış fakat güven alt boyutunda anlamlı farklılık bulunmuştur. Güven alt boyutunda kızların test puan ortalaması ile $\left(\bar{X}_{\text {güven-kız(8.smif })}=2,97\right)$ güven alt boyutunda erkeklerin test puan ortalaması $\left(\bar{X}_{\text {güven- }}\right.$ $\operatorname{erkek}(8$. ssmıf $)=2,60)$ şeklinde olup kızların lehine anlamlı bir farklı1ık saptanmıştır $\left[\mathrm{t}_{(54)}=2,15 ; \mathrm{p}<, 05\right]$.

Tablo 12'de tüm sınıfların karşılaştırılması Yazma Eğilimi Ölçeğinde bulunan güven, süreklilik ve tutku alt boyutlarında tek tek yapılmıştır.

Tablo 12

Tüm Sinıfların Yazma Eğilimi Ölçeğinin Alt Boyutlarına Göre Analiz Sonuçları

\begin{tabular}{|c|c|c|c|c|c|c|c|}
\hline Alt Boyutlar & $\begin{array}{c}\text { Varyansın } \\
\text { Kaynağı }\end{array}$ & $\begin{array}{l}\text { Kareler } \\
\text { Toplamı }\end{array}$ & sd & $\begin{array}{c}\text { Kareler } \\
\text { Ortalaması }\end{array}$ & $F$ & $p$ & Anlamlı Fark \\
\hline \multirow{3}{*}{ Güven } & Gruplar aras1 & 6,33 & 6 & 1,06 & 1,44 & ,20 & - \\
\hline & Gruplar içi & 210,55 & 287 & ,73 & & & \\
\hline & Toplam & 216,88 & 293 & & & & \\
\hline \multirow{3}{*}{ Süreklilik } & Gruplar aras1 & 12,63 & 6 & 2,11 & 2,37 & ,03 & 5. $\sin 1 f-8 . \sin 1 f$ \\
\hline & Gruplar içi & 254,98 & 287 &, 89 & & & \\
\hline & Toplam & 267,61 & 293 & & & & \\
\hline \multirow[b]{2}{*}{ Tutku } & Gruplar aras 1 & 27,32 & 6 & 4,54 & 6,19 & ,00 & 2. sinif - 8. Sinif \\
\hline & $\begin{array}{l}\text { Gruplar içi } \\
\text { Toplam }\end{array}$ & $\begin{array}{l}210,33 \\
237,56\end{array}$ & $\begin{array}{l}287 \\
293\end{array}$ & ,73 & & & $\begin{array}{l}\text { 4. sinif - 7. Sinif } \\
\text { 4. sinif - 8. Sinif } \\
\text { 5. sinif - 7. Sinif } \\
\text { 5. sinif - 8. sinif }\end{array}$ \\
\hline
\end{tabular}

Tablo 12 incelendiğinde güven alt boyutunda sınıflar arsında herhangi bir farklılık bulunmamıştır. Süreklilik alt boyutu incelendiğinde sinıflar arasında ,03 değerinde anlamlı bir farklılık tespit edilmiştir. $\mathrm{Bu}$ farklılı̆̆ın kaynağ 1 , beşinci sınıflar $\left(\bar{X}_{\text {süreklilik }(5 . \operatorname{sinı} f)}=2,88\right)$ ve sekizinci sınıflar $\left(\bar{X}_{\text {süreklilik(8.sunff }}=2,92\right)$ arasında sekizinci sınıflar lehine tespit edilmiştir $\left[\mathrm{F}_{(6-293)}=2,37, \mathrm{p}<, 05\right]$. Tutku alt boyutu incelendiğinde, sınıflar arasında, 00 değerinde anlamlı farklılık olduğu sonucuna ulaşılmıştır. Bu anlamlı farkl11ıklar: ikinci sinıflar $\left(\bar{X}_{\text {tutku(2.smif })}=3,16\right)$ ve sekizinci sinıflar $\left(\bar{X}_{\text {tutku }(8 . \operatorname{sinf} f}=2,44\right)$ arasında ikinci sınıflar lehine, üçüncü sınıflar $\left(\bar{X}_{\text {tutku(3.sinıf }}=3,23\right)$ ve sekizinci sınıflar $\left(\bar{X}_{\text {tutku(8.sinff })}=2,44\right)$ arasında üçüncü sınıflar lehine, dördüncü sinıflar $\left(\bar{X}_{\text {tutku(4.smif })}=3,20\right)$ ve yedinci $\operatorname{sinıflar~}\left(\bar{X}_{\text {tutku(7.smif }}=2,60\right)$ arasında dördüncü siniflar lehine, dördüncü sinıflar $\left(\bar{X}_{\text {tutku(4.sinif })}=3,20\right)$ ve sekizinci $\sin$ flar $\left(\bar{X}_{\text {tutku( } 8 \text { ssmif })}\right.$ $=2,44)$ arasında dördüncü sinıflar lehine, beşinci sinıflar $\left(\bar{X}_{\text {tutku( } 5 \text { ssmiff }}=3,14\right)$ ve yedinci sinıflar $\left(\bar{X}_{\text {tutku(7.smıf })}=2,60\right)$ arasında beşinci sınıflar lehine, beşinci sınıflar $\left(\bar{X}_{\text {tutku(5.smıf }}=3,14\right)$ ve sekizinci sinıflar $\left(\bar{X}_{\text {tutku(8.smif })}=2,44\right)$ arasında beşinci sinıflar lehine anlamlı farklılıklar yapılan analizler sonucunda bulunmuştur $\left[\mathrm{F}_{(6-293)}=6,19 ; \mathrm{p}<, 05\right]$.

\section{Sonuç, Tartışma ve Öneriler}

Araştırmadan elde edilen sonuçlara göre, kız öğrencilerin erkek öğrencilere göre yazma eğilimlerinin yüksek olduğu görülmüştür. Kızlar erkeklere göre yazı yazmaya daha hevesli, daha heyecanlı olduğu söylenebilir. Tüm sinıf düzeylerini kapsayan cinsiyete göre yapılan analiz sonuçlarında, yazma eğilimi ölçeğinin güven ve tutku alt boyutunda anlamlı farklılık bulunmuş, süreklilik boyutunda anlamlı bir farklılık sonucuna ulaşılmamıştır.

Sınıf sınıf cinsiyet değişkenine bakıldığında; ilkokul düzeyi olan ikinci, üçüncü ve dördüncü sınıflarda anlamlı bir farklılık yoktur. İlkokullarda yazma eğilimi cinsiyete göre farklılık göstermemektedir. Ortaokul düzeyine geçildiğinde cinsiyete göre farklılaşma başlamıştır. Beşinci ve altıncı sinıfların güven ve tutku alt boyutlarında ve sekizinci sınıfların güven alt boyutunda anlamlı farklılık vardır. Ortaokul düzeyinde her sınıfta en az bir boyutta anlamlı farklılık olmasına rağmen yedinci sınıflarda herhangi bir alt boyutta anlamlı farklılık çıkmamıştır. 
Cocuk, Yelken ve Ozer (2016) yapmış oldukları çalışmada kız öğrencilerin yazma kaygısının daha düşük olduğunu bulmuşlardır. Bu araştırma ile kız öğrencilerin yazma kaygısının düşük olması yazma eğilimlerinin yüksek olduğunun göstergesidir. Baş ve Şahin'in (2013) ilköğretim öğrencileri (6., 7. ve 8. sınıflar) ile yapmış olduğu yazma eğilimi çalışmasında, kız öğrenciler ile erkek öğrenciler arasında anlamlı farklılık bulmuşlardır. Kız öğrencilerinin yazma eğilimlerinin erkek öğrencilerin yazma eğilim düzeylerinden yüksek olduğu sonucuna ulaşmışlardır. Çeçen ve Deniz (2015) dokuzuncu, onuncu, on birinci ve on ikinci sınıflarla yapmış oldukları çalışmada kızların yazma eğilim düzeylerinin erkeklerden fazla olduğunu bulmuşlardır. Arslan ve Durukan (2015) araştırmasında İșeri ve Ünal'ın (2010) uyarlamış olduğu ölçeği kullanmışlardır. Yaptıkları araştırma sonucunda sadece tutku alt boyutunda anlamlı farklılık bulmuşlardır buna rağmen tüm alt boyutlarda kızların yazma eğilim düzeyleri erkeklerin yazma eğilim düzeylerinden daha fazladır.

Uçgun (2014) altıncı sınıflarla yapmış olduğu çalışmasında kız öğrencilerin yazma eğilimlerinin erkek öğrencilerden daha yüksek olduğu sonucuna ulaşmışlardır. Buna rağmen Tabak ve Topuzkanamış (2014) altıncı sınıflarla yapmış olduğu yazma eğilimi araştırmasında kız öğrenciler ve erkek öğrencileri arasında anlamlı bir farklılık bulmuştur. Fakat yukarıdaki çalışmalarda olduğu gibi kızların yazma eğilimi yüksek değil erkek öğrencilerin yazma eğilim düzeyleri daha yüksek çıkmıştır. Bağcı'nın (2017) beşinci ve sekizinci sınıflarla yapmış olduğu çalışmada, beşinci ve sekizinci sınıfların cinsiyete göre karşılaştırılmasında erkeklerin yazma eğilim puanları kızlarınkinden yüksek çıkmıştır. Alan yazında genel olarak kız öğrencilerin yazma eğilimlerinin yüksek olduğu görülmektedir. Bağc1 (2017) ile Tabak ve Topuzkanamış'ın (2014) çalışması alan yazına farklı bir boyut katmış ve farklı sonuçlar çıkabileceğini ortaya koymuştur.

Sınıflar arasındaki yazma eğilimi incelendiğinde, güven alt boyutunda sınıflar arasında herhangi bir farklılık bulunmamıştır. Süreklilik boyutunda beşinci sınıflar ve sekizinci sınıflar arasında anlamlı bir farklılık bulunmuştur. Beşinci sınıfların ortalamasının sekizinci sınıflardan yüksek olduğu da sonuçlar arasındadır. Süreklilik alt boyutunda sınıf seviyesi azaldıkça yazma eğilimi yükselmektedir denilebilir. Tutku alt boyutunun sonuçlarına bakıldığında ise; ikinci, üçüncü, dördüncü ve beşinci sınıflarda sekizinci sınıflar arasında anlamlı bir farklılık bulunmuştur. Bu anlamlı farklılıkların hepsi sınıf düzeyi küçük olan taraftadır. Sınıf seviyesi artıkça öğrencilerin yazma eğilimlerinin ortalamasının düştüğü görülmüştür. Sınıf seviyesi artıkça öğrencilerin yazma hevesi ve heyecanının da düştüğü söylenebilir. Sekizinci sınıftaki öğrencilerin yazma eğilim düzeyleri genele bakıldığında diğer sınıflardan daha düşüktür. Ayrıca dördüncü ve beşinci sınıfların hem yedinci sınıflarla hem de sekizinci sınıflarla arasında anlamlı farklılık vardır. Sınıf düzeyi artıkça yazma eğilimindeki düşüşten kaynaklanmaktadır bu farklılıklar.

Baş ve Şahin (2013) altıncı, yedinci ve sekizinci sınıflarla yapmış olduğu çalışmasında, sınıflar arasında herhangi bir farklılık bulmamıştır. Baş ve Şahin (2013), İşeri ve Ünal'ın (2010) uyarlamış olduğu bu çalışmada da kullanılan ölçeği kullanmışlardır. Bu çalışmada da altıncı, yedinci ve sekizinci sınıflar arasında da anlamlı bir farklılık bulunmamıştır. Yapılan bu iki araştırma birbirini sınıf düzeyleri değişkeninde (6., 7. ve 8. sınıflar) birbirini desteklemektedir. Arslan ve Durukan (2015) beşinci, altıncı, yedinci ve sekizinci sınıflarda aynı ölçeği uygulamıştır. Araştırma sonucunda süreklilik alt boyutunda yedinci sınıflar ile sekizinci sınıflar arasında yedinci sınıflar lehine farklılık tespit etmişlerdir. Bağcı (2017) beşinci ve sekizinci sınıflara İșeri ve Ünal'ın (2010) ölçeğini uygulamışlardır. Beşinci ve sekizinci sınıflar arasında beşinci sınıf lehine bir farklılık bulmuşlardır. Beşinci sınıfların yazma eğilim puanları sekizinci sınıflardan daha yüksek olduğunu tespit etmişlerdir.

Çeçen ve Deniz (2015) liselerde yazma eğilimini İşeri ve Ünal'ın (2010) uyarlamış olduğu ölçekle ölçmüşlerdir. Yapılan analizler sonucunda dokuzuncu, on birinci ve on ikinci sınıflar arasında anlamlı farklılıklar bulmuşlardır. Sınıf seviyesi artıkça öğrencilerin yazma eğilim düzeylerinin düştüğü sonucuna da ulaşmışlardır. Bu çalışmada da sınıf düzeyi artıkça yazma eğiliminin düştüğü bulunmuştur. İlkokul, ortaokul veya lise fark etmeksizin sınıf seviyesi artıkça yazma eğiliminde düşüş olduğu sonucuna varılabilir. 
Yukarıda bahsedilen çalışmalar ve yapılan bu çalışma sınıf seviyesi artıkça öğrencilerin yazma eğilimlerinin düştüğünü göstermektedir. Berk ve Ünal'ın (2017) yapmış oldukları çalışmada yazma eğilimin, yazma kaygısı ve öğrencilerin not düzeyleri ile ilgili olduğu sonucuna ulaşmışlardır. Sınıf düzeyi artıkça öğrencilerin yazma eğilimlerinin düşmesinin sebebi, öğrencilerin yazma kaygılarının da yükseldiği söylenebilir. Cocuk, Yelken ve Ozer (2016) de yapmış oldukları çalışmada yazma kaygısı ile yazma eğilimi arasında bir ilişki bulmuşlardır. Yazma kaygısı yüksek olan öğrencileri yazma eğilimlerinin düşük olduğunu bulmuşlardır.

Araştırmanın sonuçları doğrultusunda bazı önerilerde bulunulmuştur:

- Sınıf seviyesi artıkça yazma eğilimi düştüğü görülmüştür bu sebeple sınıf seviyesi artıkça öğrencilerin yazma eğilimlerini artırmaya yönelik çalışmalar yapılmalıdır.

- Okullarda öğrencilerin yazma eğilimlerini yükseltmeye yönelik etkinlikler yapılmalıdır.

- Okuma geliştikçe yazma da gelişir fikrinden hareketle okumaya yönelik tutumlarının da geliştirilmesine önem verilmelidir.

- Öğrencilerin okuduklarına yönelik olarak duygu ve düşüncelerini yazıyla anlatma becerilerinin de geliştirilmesi için destekleyici etkinlikler geliştirilmelidir.

- Türkçe öğretim programlarının öğrencilerin yazma becerilerini geliştirici nitelikte olması öğrencilerin istenen düzeyde yazma becerisi ve yazma eğilimi göstermeleri sağlanmalıdır.

- Bu çalışma ilkokul ve ortaokul seviyelerinde yapılmıştır. Lise ve üniversitelerde de yazma eğilimi çalışması yapılarak daha genel sonuçlara ulaşılabilir.

\section{Yazarların Katkı Oranı}

Bu makaleye birinci yazarın \%40, ikinci yazarın \%30, üçüncü yazarın $\% 30$ oranında katkısı vardir.

\section{Çıkar Çatışması}

Bu çalışmada çıkar çatışması oluşturacak bir husus yoktur.

Açıklama: Bu çalı̧̧ma, 24-26 Nisan 2017 tarihlerinde Antalya'da gerçekleşen I. Uluslararası Sınırsız Eğitim ve Araştırma Sempozyumu'nda (USEAS 2017) sözlü bildiri olarak sunulmuştur.

\section{Kaynaklar}

Aktaş, Ş., ve Gündüz, O. (2003). Yazılı ve sözlü anlatım kompozisyon sanatı. Ankara: Akçağ Yayınları.

Arslan, N., ve Durukan, E. (2015). Ortaokul öğrencilerinin öğrenme stilleri ve yazma eğilimleri arasındaki ilişki. Uluslararası Türkçe Edebiyat Kültür Eğitim (TEKE) Dergisi, 4(3), 1251-1267. https://dergipark.org.tr/download/article-file/137067.

Aydın Yılmaz, Z. (2007). Sınıf ögrretmenlerine Türkçe öğretimi. Ankara: Nobel Yayın Dağıtım.

Baş, G., ve Şahin, C. (2013). İlköğretim öğrencilerinin yazma eğilimlerinin farklı değişkenler açısından incelenmesi. Sakarya University Journal of Education, 3(1), 32-42. https://dergipark.org.tr/download/article-file/192294.

Belet, D. Ş., ve Yaşar, Ş. (2007). Öğrenme stratejilerinin okuduğunu anlama ve yazma becerileri ile Türkçe dersine ilişkin tutumlara etkisi. Eğitimde Kuram ve Uygulama, 3(1), 69-86. https://dergipark.org.tr/download/article-file/63272. 
Berk, R. R., ve Ünal, E. (2017). Comparison of writing anxiety and writing dispositions of sixth, seventh and eighth grade students. International Journal of Instruction, 10(1), 237-254. https://files.eric.ed.gov/fulltext/EJ1125149.pdf.

Cemaloğlu, N., (2001). İlk okuma yazma öğretimi. Ankara: Nobel Yayın Dağıtım.

Cocuk, H. E., Yanpar Yelken, T., ve Ozer, Ö. (2016). The relationship between writing anxiety and writing disposition among secondary school students. Eurasian Journal of Educational Research, 16(63), 335-352. https://dergipark.org.tr/download/article-file/225139.

Çeçen, M. A. ve Deniz, E. (2015). Ortaöğretim öğrencilerinin yazma eğilimi algıları (Diyarbakır ili örneği). Ana Dili Ĕgitimi Dergisi, 3(2), 35-48. http://www.anadiliegitimi.com/download/articlefile/14918.

Güneş, F. (2007a). Türkçe öğretimi ve zihinsel yapılandırma. Ankara: Nobel Yayın Dağıtım.

Güneş, F. (2007b). Ses temelli cümle yöntemi ve zihinsel yapılandırma. Ankara: Nobel Yayın Dağıtım.

Güneş, F. (2013). Türkçe ögrretimi yaklaşımlar ve modeller. Ankara: Pegem Akademi.

İşeri, K., ve Ünal, E. (2010). Yazma Eğilimi Ölçeği'nin Türkçeye uyarlanması. Eğitim ve Bilim, 35(155), 104-117.

Karasar, N. (2017). Bilimsel araştırma yöntemi: Kavramlar ilkeler teknikler (İkinci yazım, 32. bask1). Ankara: Nobel Akademik Yayıncılık.

McClenny, C. S. (2010). A disposition to write: Relationships with writing performance. Doctoral Dissertation. Florida State University, USA.

MEB. (2015). Türkçe dersi (1-8. sinıflar) ögretim programı. Ankara.

MEB. (2017). Türkçe ögrretim dersi ögretim programı (ilkokul ve ortaokul 1, 2, 3, 4, 5, 6, 7 ve 8. sinıflar). Ankara.

MEB. (2019). Türkçe dersi öğretim programı (ilkokul ve ortaokul 1, 2, 3, 4, 5, 6, 7, ve 8. sinıflar). Ankara.

Piazza, C. L., ve Siebert, C. F. (2008). Development and validation of a writing dispositions scale for elementary and middle school students. The Journal of Educational Research, 101(5), 275-286. doi:https://doi.org/10.3200/JOER.101.5.275-286

Sidekli, S. (2012). Yazma becerisinin geliştirmek için hikâye piramidi. Akademik Bakış Dergisi, 31, 118.

Tabak, G., ve Topuzkanamış, E. (2014). An analysis of writing dispositions of 6th grade students in terms of different variables. Online Submission, 4(2), 1-11. doi:http://dx.doi.org/10.13054/mije.14.15.4.2

Uçgun, D. (2014). Altıncı sınıf öğrencilerinin yazma eğilimlerinin incelenmesi. Eğitim ve Bilim, 39(175), 227-238. doi:http://dx.doi.org/10.15390/EB.2014.1176 


\section{Extended Abstract}

\section{Introduction}

Learning areas were included in the Ministry of National Education (MoNE) (2019) Turkish Lesson Curriculum as listening, speaking, reading and writing. Speaking and listening to the four basic language skills can be gained to some extent outside of the school, but gaining reading and writing skills is the job of formal education and these skills are tried to be gained through Turkish lessons in primary education institutions (Belet and Yaşar, 2007).

Students' being a good writer, writing love and writing habit are one of the main objectives of Turkish Education Program (MoNE, 2015; 2017; 2019). The purpose of writing Aktaş and Gündüz (2003) is by making use of the individual's observation and knowledge; He stated that he reflected his feelings and thoughts to the reader in a beautiful, correct and effective way.

McClenny (2010) says that writing disposition consists of three dimensions: cognition, emotion and social context. Piazza and Siebert (2008) stated that the tendency to write includes three different emotional dimensions: trust, determination and passion.

The aim of the research is to examine the writing tendencies of primary and secondary school (2nd, 3rd, 4th, 5th, 6th, 7th and 8th grade) students in terms of class and gender variable and to determine the writing levels of primary and secondary school students.

\section{Method}

The research was made with the screening model, which is one of the quantitative research types, and it was made with the general screening model. The sample consists of 294 students studying in 4 official village primary schools and village secondary schools in different districts of Muğla city center.

The "Writing Tendency Scale", which was developed by Piazza and Siebert (2008) and translated and adapted into Turkish by İşeri and Ünal (2010), was used as the data collection tool in the study. Descriptive statistics such as arithmetic mean and standard deviation of their responses to the Writing Tendency Scale were calculated. Independent groups t-test was used for comparisons based on gender, and one-way variance (ANOVA) analysis was used for comparisons based on class level variables. Dunnett - C analysis was performed in order to detect significant difference in one-way analysis of variance.

\section{Findings}

In order to reveal whether there is a significant difference in writing sub-dimensions according to gender in all sub-dimensions, unrelated samples t-test was conducted. A significant difference was found between the test score average of the girls $\left(\bar{X}_{\text {confidence-girl }}=3,09\right)$ in the trust sub-dimension and the test score average of the boys $\left(\bar{X}_{\text {confidence-boy }}=2,77\right)$ in the confidence sub-dimension $\left[\mathrm{t}_{(292)}=3,27, \mathrm{p}<, 05\right]$. Considering the continuity sub-dimension, there was no significant difference between the test score average of the girls $\left(\bar{X}_{\text {continuity-girl }}=2,54\right)$ and the test score average of the boys $\left(\bar{X}_{\text {continuity-boy }}=2,51\right)\left[\mathrm{t}_{(292)}\right.$ $=, 22 ; \mathrm{p}>, 05]$. When the passion sub-dimension is examined; As a result of the analysis, there was a significant difference between girls' tests score average $\left(\bar{X}_{\text {passion-girl }}=3,00\right)$ and boys' test score average $\left(\bar{X}_{\text {passion-boy }} 2,76\right)$ in favor of girls $\left[\mathrm{t}_{(292)}=2,33 ; \mathrm{p}<, 05\right]$. There was a significant difference in the dimensions of trust and passion in the sub-dimensions according to gender, but no significant difference in the continuity sub-dimension. Although there was no significant difference in the continuity subdimension, the writing disposition score averages of girls were higher than the writing tendency score averages of boys. 
When all sub-dimensions of writing disposition scale are analyzed by grade levels; There was no difference between the classes in the trust sub-dimension. When the continuity sub-dimension was examined, a significant difference was found between the classes at the value of, 03 . The source of this difference has been determined in favor of the eighth grade among the fifth grade $\left(\bar{X}_{\text {continuity(5th grade })}=\right.$ $2,88)$ and the eighth grade $\left(\bar{X}_{\text {continuity }(8 \text { th grade })}=2,92\right)\left[\mathrm{F}_{(6-293)}=2,37 ; \mathrm{p}<, 05\right]$. When the passion subdimension is examined, it is concluded that there is a significant difference in the value of, 00 between the classes. These significant differences: between the second $\left(\bar{X}_{\text {passion(2nd grade) }}=3,16\right)$ and eighth grade $\left(\bar{X}_{\text {passion(8th grade })}=2,44\right)$ in favor of the second-grade classes, between the third $\left(\bar{X}_{\text {passion(3rd grade })}=3,23\right)$ and eighth grade $\left(\bar{X}_{\text {passion( } 8 \text { th grade })}=2,44\right)$ in favor of the third-grade classes, between the fourth $\left(\bar{X}_{\text {passion(4th grade })}\right.$ $=3,20)$ and seventh grade $\left(\bar{X}_{\text {passion(7th grade })}=2,60\right)$ in favor of the fourth-grade classes, between the fourth $\left(\bar{X}_{\text {passion(4th grade })}=3,20\right)$ and eighth grade $\left(\bar{X}_{\text {passion(8th grade })}=2,44\right)$ in favor of the fourth-grade classes, between the fifth $\left(\bar{X}_{\text {passion(5th grade })}=3,14\right)$ and seventh grade $\left(\bar{X}_{\text {passion(7th grade })}=2,60\right)$ in favor of the fifthgrade classes, between the fifth $\left(\bar{X}_{\text {passion(5th grade })}=3,14\right)$ and eighth grade $\left(\bar{X}_{\text {passion(8th grade })}=2,44\right)$ in favor of the fifth-grade classes as a result of the analyzes $\left[\mathrm{F}_{(6-293)}=6,19 ; \mathrm{p}<, 05\right]$.

\section{Conclusion, Discussion and Recommendations}

According to the results obtained from the research, it was observed that female students have a high tendency to write compared to male students. It can be said that girls are more enthusiastic and more excited to write than boys. As a result of the analysis conducted by gender that covers all grade levels, a significant difference was found in the trust and passion sub-dimension of the writing disposition scale, and no significant difference was found in the continuity dimension.

When the tendency to write between the classes was analyzed, no difference was found between the classes in the trust sub-dimension. A significant difference was found between the fifth grades and the eighth grades in terms of continuity. It can be said that the tendency to write increases as the grade level decreases in the continuity sub-dimension. Looking at the results of the passion sub-dimension; A significant difference was found between the eighth grades in the second, third, fourth and fifth grades. All of these significant differences are on the side where the grade level is small. As the grade level increased, the average of students' writing disposition decreased. It can be said that the enthusiasm and excitement of writing decreases as the grade level increases.

As a result of the research, the following suggestions were made;

- As the grade level increased, it was observed that the writing disposition decreased, so studies should be carried out to increase the writing disposition of students as the grade level increases.

- Activities should be held in schools to increase students' writing disposition.

- It should be ensured that the Turkish curriculum improves students' writing skills, and that students show the writing skills and the tendency to write at the desired level. 